\title{
Effects of Funneliformis mosseae on the fungal community and soil properties in a continuously cropped soybean system
}

\author{
$\mathrm{Na} \mathrm{Guo}^{1}$, Liang $\mathrm{Li}^{1}$, Qi $\mathrm{Cui}^{2}$, and Baiyan $\mathrm{Cai}^{2}$ \\ ${ }^{1}$ Affiliation not available \\ ${ }^{2}$ Heilongjiang University
}

August 20, 2020

\begin{abstract}
Abstract: Root rot leads to a significant decline in the production and quality of soybean, particularly in continuous cropping systems. Therefore, it is important to explore methods and mechanisms for the biocontrol of root rot pathogens. In this paper, the community structure of fungi in the root and rhizosphere soil was determined by high-throughput sequencing technology under non-inoculated and Funneliformis mosseae-inoculated conditions. Moreover, redundancy analysis (RNA) was used to analyse the effects of F. mosseae on the community structure of fungi and the physical and chemical properties of soil. In different samples (root and rhizosphere soil), the index of fungal diversity in HN48 was higher than that in HN66, while that without F. mosseae inoculation was slightly higher than that under inoculation with F. mosseae in different years of continuous cropping. Compared to non-inoculated plants, Fusarium oxysporum and Rhizoctonia solani were the dominant fungi in different root samples of soybean varieties. However, the predominant genera in the rhizosphere soil samples shifted with inoculation and comprised Fusarium, Mortierella, Cryptococcus, Guehomyces and Corynespora. Moreover, after inoculation with F. mosseae, the relative abundance of F. oxysporum and R. solani decreased in root and rhizosphere soils. Additionally, RDA showed that the rhizosphere soil had significant differences depending on F. mosseae inoculation, continuous cropping years, and soybean varieties. This study provides new insights into the interactive effects of arbuscular mycorrhizal fungi (AMF) and other fungi in continuously cropped soybean systems.
\end{abstract}

\section{Hosted file}

Manuscript MEC.doc available at https://authorea.com/users/352337/articles/476643-effectsof-funneliformis-mosseae-on-the-fungal-community-and-soil-properties-in-a-continuouslycropped-soybean-system 

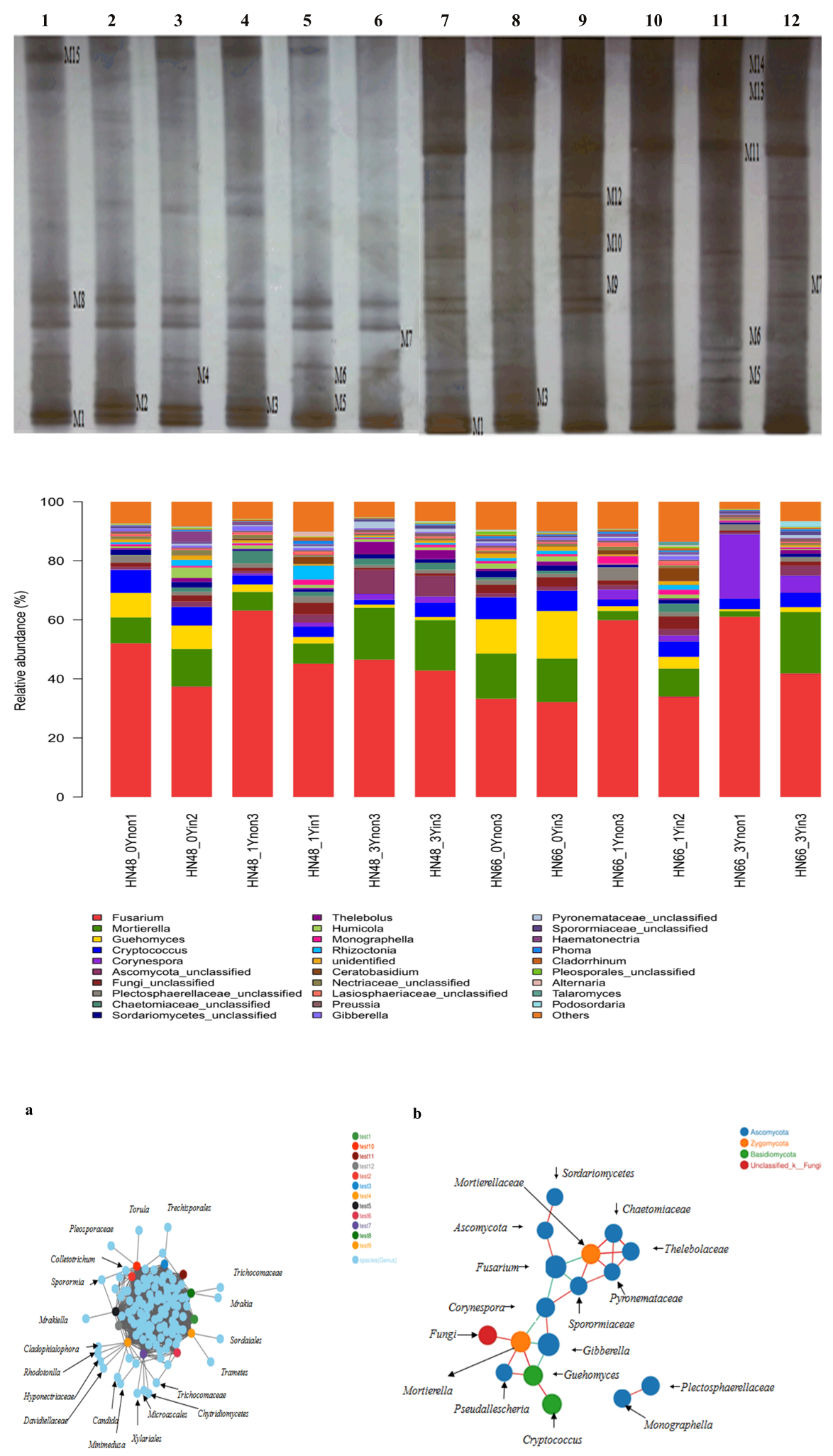

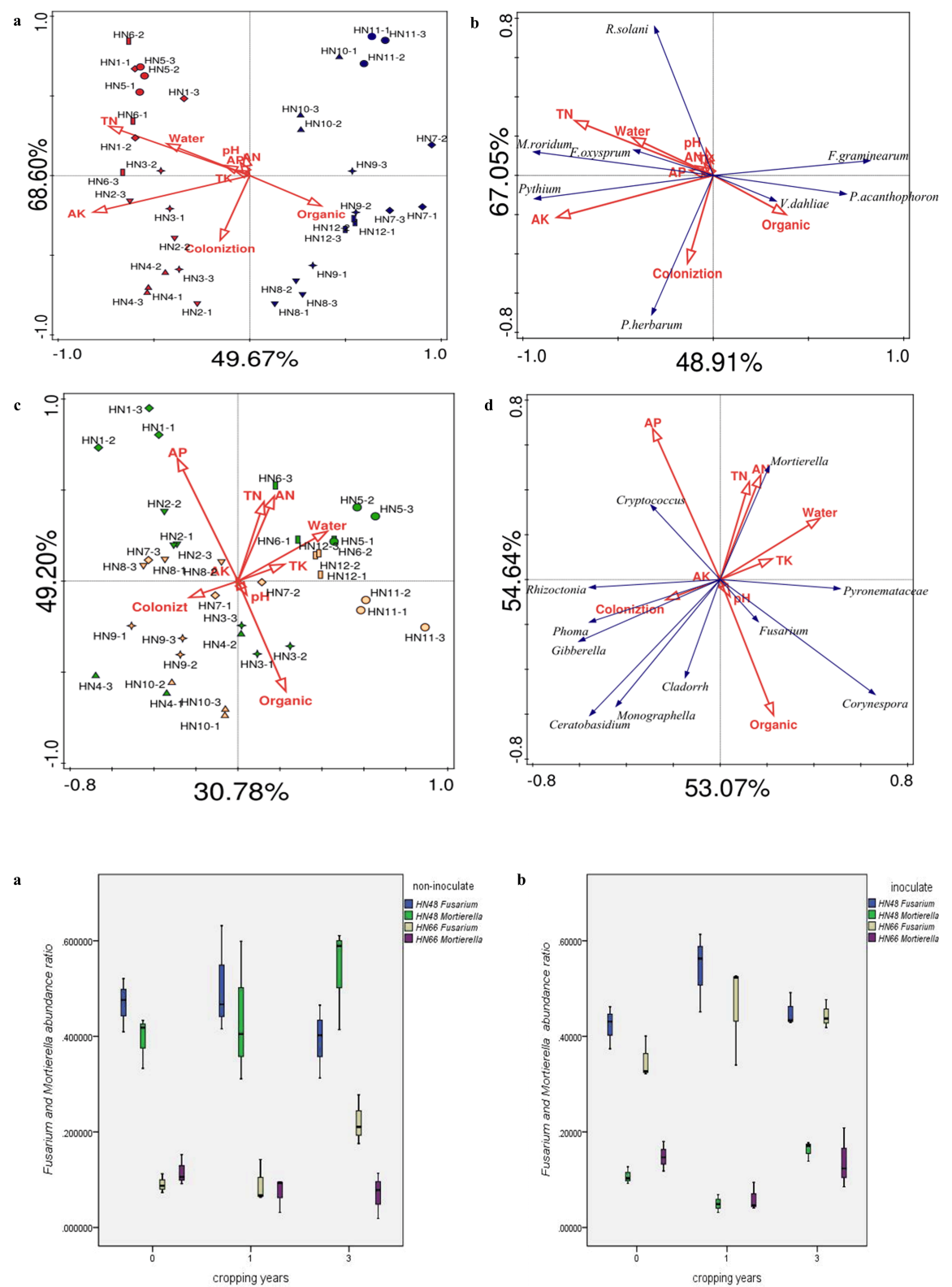

\section{Hosted file}

Table 1 .docx available at https://authorea.com/users/352337/articles/476643-effects-offunneliformis-mosseae-on-the-fungal-community-and-soil-properties-in-a-continuouslycropped-soybean-system

\section{Hosted file}

Table 2.docx available at https://authorea.com/users/352337/articles/476643-effects-offunneliformis-mosseae-on-the-fungal-community-and-soil-properties-in-a-continuouslycropped-soybean-system

\section{Hosted file}


Table 3.docx available at https://authorea.com/users/352337/articles/476643-effects-offunneliformis-mosseae-on-the-fungal-community-and-soil-properties-in-a-continuouslycropped-soybean-system

\section{Hosted file}

Table 4.docx available at https://authorea.com/users/352337/articles/476643-effects-offunneliformis-mosseae-on-the-fungal-community-and-soil-properties-in-a-continuouslycropped-soybean-system

\section{Hosted file}

Table 5.docx available at https://authorea.com/users/352337/articles/476643-effects-offunneliformis-mosseae-on-the-fungal-community-and-soil-properties-in-a-continuouslycropped-soybean-system

\section{Hosted file}

Table 6 .docx available at https://authorea.com/users/352337/articles/476643-effects-offunneliformis-mosseae-on-the-fungal-community-and-soil-properties-in-a-continuouslycropped-soybean-system 